\title{
PERFORMANCE OF SWEET GOURD AS RELAY WITH TRANSPLANTED AMAN RICE UNDER RAINFED ECOSYSTEM IN SYLHET REGION
}

\author{
M. I. Nazrul ${ }^{1}$ and M. R. Shaheb ${ }^{1}$ \\ SSO, OFRD, BARI, Sylhet-3100 \\ Correspondence author: mi_nazrul@yahoo.com
}

Keywords: Relay cropping, sole cropping, productivity, profitability, sweet gourd

\begin{abstract}
This study was carried out to evaluate the economic benefits of sweet gourd relay with transplanted aman rice under farmer's field condition at Farming System Research and Development (FSRD) site, Jalalpur and Multi Location Testing (MLT) site, Zakigonj of Sylhet region during 2012-2013 and 2013-2014. The treatment combinations $\mathrm{T}_{1}$ : $\mathrm{T}$. aman rice / sweet gourd (var. Mollika), $\mathrm{T}_{2}: \mathrm{T}$. aman rice / sweet gourd (var. Hatirpara) local, $\mathrm{T}_{3}$ : Sweet gourd (var. Mollika) sole, $\mathrm{T}_{4}$ : Sweet gourd (var. Hatirpara) sole and $\mathrm{T}_{5}$ : $\mathrm{T}$. aman rice sole (var. Binadhan-7) was maintained. The study was based in a randomized complete block $(\mathrm{RCB})$ design with six dispersed replications. Results in terms of the crops yield, rice equivalent yield, gross return and net return with benefit cost ratio showed higher in sweet gourd / transplanted aman rice relay cropping system. So, sweet gourd relayed with transplanted aman rice could be an economically viable technology, instead of sole cropping, for best utilization of fallow land with residual soil moisture in Sylhet region.
\end{abstract}

\section{Introduction}

The vast areas of Surma Kushiyara Flood Plain soil in Sylhet region of AEZ 20 remain fallow in each year during rabi season due to lack of irrigation facilities. Soil moisture goes down quickly after harvest of T. Aman rice and consequently the land remains fallow for a substantial period of about 4-5 months (Nazrul et al., 2013). It is a general practice of the farmers to grow various winter crops in the field after the harvest of transplanted aman rice though the residual moisture is inadequate for proper growth of the plants. The relay cropping with other crops like lathyrus, rapeseed, mustard, potato and other vegetables are providing more remuneration to the farmers instead of sole crops (Gupta and Bhowmick, 2005). It is also ensuring the germination by utilizing the existing residual soil moisture and to avoid tillage operations during crop growing. It assume that such relay cropping system can increase the uptake and use efficiency of inputs because of growing of two crops in different times. Sweet gourd (Cucurbita moschata) is a promising vegetable in Bangladesh which can be grown in well-drained fertile soils with $\mathrm{pH}$ between 6.0 and 6.5. The pumpkin has a high content of vitamin $\mathrm{D}$ as well as minerals like copper, iron and phosphorus. Fallow-T. aus-T. aman rice is the dominant cropping pattern in this region under rainfed condition in medium highland to lowland areas of Surma-Kushyara Floodplain. T. aus rice is being depended on rainfall and usually transplanting is done in early May. This delayed transplantation of aus rice, hampered the timely cultivation of subsequent $T$. aman rice and resulting delay sowing of rabi crops. In Sylhet, farmers facing problems with the cultivation of sweet gourd especially delayed sowing of seeds, seedlings establishment in the field and lack of irrigation facilities etc. It is noted that these $\mathrm{T}$. aman rice cultivated areas in medium highland can be easily brought under relay cultivation with sweet gourd with minimum moisture resulting in increase of total productivity with minimum cost. So, there is an opportunity to 
Nazrul et al.

cultivate sweet gourd as relay crop in T. aman rice field. With this view, the present study has been designed to evaluate the economic benefits of sweet gourd relay with transplanted aman rice under AEZ 20 in Sylhet region.

\section{Materials and Methods}

This experiment was carried out under farmer's field conditions at Farming System Research and Development (FSRD) site, Jalalpur and Multi Location Testing (MLT) site, Zakigonj of Sylhet region during 2012-2013 and 2013-2014. The treatment combinations were as $\mathrm{T}_{1}$ : T. aman rice/sweet gourd (var. Mollika), T2: T. aman rice/sweet gourd (var. Hatirpara) local, $\mathrm{T}_{3}$ : Sweet gourd (var. Mollika) sole, $\mathrm{T}_{4}$ : Sweet gourd (var. Hatirpara) sole and $\mathrm{T}_{5}$ : $\mathrm{T}$. aman rice sole (var. Binadhan-7). The study was based in a randomized complete block (RCB) design with six dispersed replications. The seedlings of T. aman rice were transplanted on 10-15 August and harvested on 15-20 November in each year. Monthly average maximum and minimum temperatures and rainfall data are presented in Fig. 1. The sweet gourd seeds were sown 15-20 days before harvest of T. aman rice by making heap called 'Mada' with maintaining the distance is $2 \mathrm{~m} 2 \mathrm{~m}$. Three to five seeds of sweet gourd of each variety were sown in each Mada as relay on 28 October to 5 November in T. aman rice field, while sweet gourd sole was sown on 23-28 November after harvest of $T$. aman rice. The size of the Mada was $50 \mathrm{~cm}$ x $50 \mathrm{~cm} 45 \mathrm{~cm}$. Fertilizers were applied @ 80-35-75-18-4-2 and 70-11-40-10-1-0 Kg ha ${ }^{-1}$ of NPKSZnB for sweet gourd and T. aman rice in the form of Urea, TSP, MoP, Gypsum, Zinc sulphate and Boric acid, respectively (FRG. 2012). Cow dung $3 \mathrm{t} \mathrm{ha}^{-1}$ was applied for sweet gourd. Methods of fertilizer application were maintained as per FRG (2012) and Mondal et al. (2011). The sex pheromone trap along with poison bait was used for controlling the fruit fly. Malathion 57EC @ 2ml/L and Tilt 250EC @ 1ml/L were applied at an interval of 5-7 days for controlling beetle and powdery mildew, respectively. Approximate 8-10 liters of water per pit twice a week by watering was maintained to ensure better growth and fruiting of pumpkin. Hand pollination was done in some cases for more fruiting. The sweet gourds were harvested from 12 February to 30 April. Yield of individual crop was converted into equivalent yield on the basis of the prevailing market price of individual crop (Singh et al., 1990; Reddy and Reddi, 1992).

$$
\text { Rice equivalent yield }\left(\text { tha }^{-1}\right)=\mathrm{Ysr}+(\mathrm{Yis} \mathrm{Ps}) / \mathrm{Pr}
$$

Where,

$$
\begin{aligned}
& \text { Ysr }=\text { Yield of sole transplanted aman rice }\left(\mathrm{t} \mathrm{ha}^{-1}\right) \\
& \text { Yis }=\text { Yield of sweet gourd as relay }\left(\mathrm{t} \mathrm{ha}^{-1}\right) \\
& \mathrm{Pr}=\text { Selling price of rice } \\
& \mathrm{Ps}=\text { Selling price of sweet gourd }
\end{aligned}
$$

The soil moisture was monitored by gravimetric determination in 15 day intervals at $0-5 \mathrm{~cm}, 5-$ $10 \mathrm{~cm}, 10-15 \mathrm{~cm}$ and $15-20 \mathrm{~cm}$ depths. The soil samples were collected with a screw augur from the experimental plots and put in aluminum cups and after taking fresh weight, samples were kept in to a thermo statistically controlled oven for drying. At least 15 samples were collected from each spots and averages of those were used. The soil moisture content was measured by following gravimetric method (Black, 1965).

The recorded data were statistically analyzed and mean values were separated by LSD test following Gomez and Gomez (1984). All types of costs of production were recorded and cost benefit analysis with respect to net return was carried out to evaluate the profitability of different relay cropping treatment combinations. 
Sweet Gourd as Relay with Transplanted Aman Rice

\section{Results and Discussion}

The two years average yield of sweet gourd and rice grain at MLT site, Zokigonj and FSRD site, Jalalpur locations has been shown in Table 1 \& 2, respectively. Three years (2010-2013) average maximum and minimum temperature and total rainfall in Sylhet are presented in Fig.1. From the graph it was observed that the average maximum and minimum temperatures were in the months of October and January, respectively. The maximum rainfall recorded in June and almost no rainfall was found in January to February while in November to December, a very small amount of precipitation observed amounting just below $20 \mathrm{~mm}$. However, in rest of the months total rainfall was ranged from $100 \mathrm{~mm}$ to just below $800 \mathrm{~mm}$. During the period of experiments establishment showed a rapid decrease in soil moisture at the second $5-10 \mathrm{~cm}$ depth though the initial moisture level was high $28-29 \%$ (Fig. 2a-b). The initial soil moisture showed a high level in all layer up to the first few weeks of November in each year, but decrease with the increasing of time. The moisture contents of $10-15 \mathrm{~cm}$ and $15-20 \mathrm{~cm}$ layers did not show appreciable variations when compared to the top layers in both the years (Fig. 2a-b).

Table 1. Grain yield of T. aman rice and sweet gourd in relay cropping system at MLT site, Zokigonj (2012-14)

\begin{tabular}{|c|c|c|c|c|c|c|c|}
\hline \multirow[t]{3}{*}{ Treatments } & \multicolumn{6}{|c|}{ Zakigonj } & \multirow{3}{*}{$\begin{array}{c}\text { Rice equivalent } \\
\text { yield (t ha-1) }\end{array}$} \\
\hline & \multicolumn{3}{|c|}{ Sweet gourd (t ha-1) } & \multicolumn{3}{|c|}{ T. aman rice $\left(\mathrm{t} \mathrm{ha}^{-1}\right)$} & \\
\hline & 2012-13 & 2013-14 & Average & $2012-13$ & 2013-14 & Average & \\
\hline $\mathrm{T}_{1}$ & 21.46 & 17.17 & 19.32 & 3.69 & 3.79 & 3.74 & 18.23 \\
\hline $\mathrm{T}_{2}$ & 22.29 & 17.83 & 20.06 & 3.74 & 3.86 & 3.80 & 18.84 \\
\hline $\mathrm{T}_{3}$ & 16.46 & 13.17 & 14.82 & - & - & - & 11.12 \\
\hline $\mathrm{T}_{4}$ & 18.75 & 15.00 & 16.88 & - & - & - & 12.66 \\
\hline $\mathrm{T}_{5}$ & - & - & - & 3.88 & 3.92 & 3.90 & 3.90 \\
\hline $\operatorname{LSD}_{(0.05 \%)}$ & 1.93 & 1.54 & 1.74 & 0.12 & 0.07 & 0.10 & - \\
\hline CV (\%) & 6.10 & 4.88 & 5.49 & 1.37 & 0.40 & 0.89 & - \\
\hline
\end{tabular}

$\mathrm{T}_{1}$ : T. aman rice/sweet gourd (var. Mollika), $\mathrm{T}_{2}$ : T. aman rice/sweet gourd (var. Hatirpara) local, $\mathrm{T}_{3}$ : Sweet gourd (var. Mollika) sole, $\mathrm{T}_{4}$ : Sweet gourd (var. Hatirpara) sole and $\mathrm{T}_{5}$ : T. aman rice sole (var. Binadhan-7). ${ }^{*}$ Price $\left(\mathrm{Tk} . \mathrm{kg}^{-1}\right)$ : $\mathrm{T}$. aman- 16.00 and sweet gourd- 12.00

Table 2. Grain yield of T. aman rice and sweet gourd in relay of sweet gourd with T. aman rice cropping system at FSRD site, Jalalpur (2012-14)

\begin{tabular}{|c|c|c|c|c|c|c|c|}
\hline \multirow[t]{3}{*}{ Treatments } & \multicolumn{6}{|c|}{ Jalalpur } & \multirow{3}{*}{$\begin{array}{l}\text { Rice equi. yield } \\
\left.\text { (t ha }{ }^{-1}\right)\end{array}$} \\
\hline & \multicolumn{3}{|c|}{ Sweet gourd (t ha-1) } & \multicolumn{3}{|c|}{ T. aman rice $\left(\mathrm{t} \mathrm{ha}^{-1}\right)$} & \\
\hline & $2012-13$ & 2013-14 & Average & 2012-13 & 2013-14 & Average & \\
\hline $\mathrm{T}_{1}$ & 22.24 & 19.71 & 20.98 & 3.63 & 3.73 & 3.68 & 19.42 \\
\hline $\mathrm{T}_{2}$ & 23.04 & 20.42 & 21.73 & 3.72 & 3.77 & 3.75 & 20.04 \\
\hline $\mathrm{T}_{3}$ & 19.47 & 17.25 & 18.36 & - & - & - & 13.77 \\
\hline $\mathrm{T}_{4}$ & 18.10 & 15.86 & 16.98 & - & - & - & 12.73 \\
\hline $\mathrm{T}_{5}$ & - & - & - & 3.90 & 3.94 & 3.92 & 3.92 \\
\hline $\operatorname{LSD}_{(0.05 \%)}$ & 2.01 & 1.78 & 1.90 & 0.07 & 0.14 & 0.11 & - \\
\hline $\mathrm{CV}(\%)$ & 6.31 & 5.59 & 5.95 & 0.76 & 1.75 & 1.26 & - \\
\hline
\end{tabular}

$\mathrm{T}_{1}$ : T. aman rice/sweet gourd (var. Mollika), $\mathrm{T}_{2}$ : T. aman rice/sweet gourd (var. Hatirpara) local, $\mathrm{T}_{3}$ : Sweet gourd (var. Mollika) sole, $\mathrm{T}_{4}$ : Sweet gourd (var. Hatirpara) sole and $\mathrm{T}_{5}$ : T. aman rice sole (var. Binadhan-7) ***Price of output (Tk. $\left.\mathrm{kg}^{-1}\right)$ : T. aman rice- 16.00 and sweet gourd-12.00 
Nazrul et al.

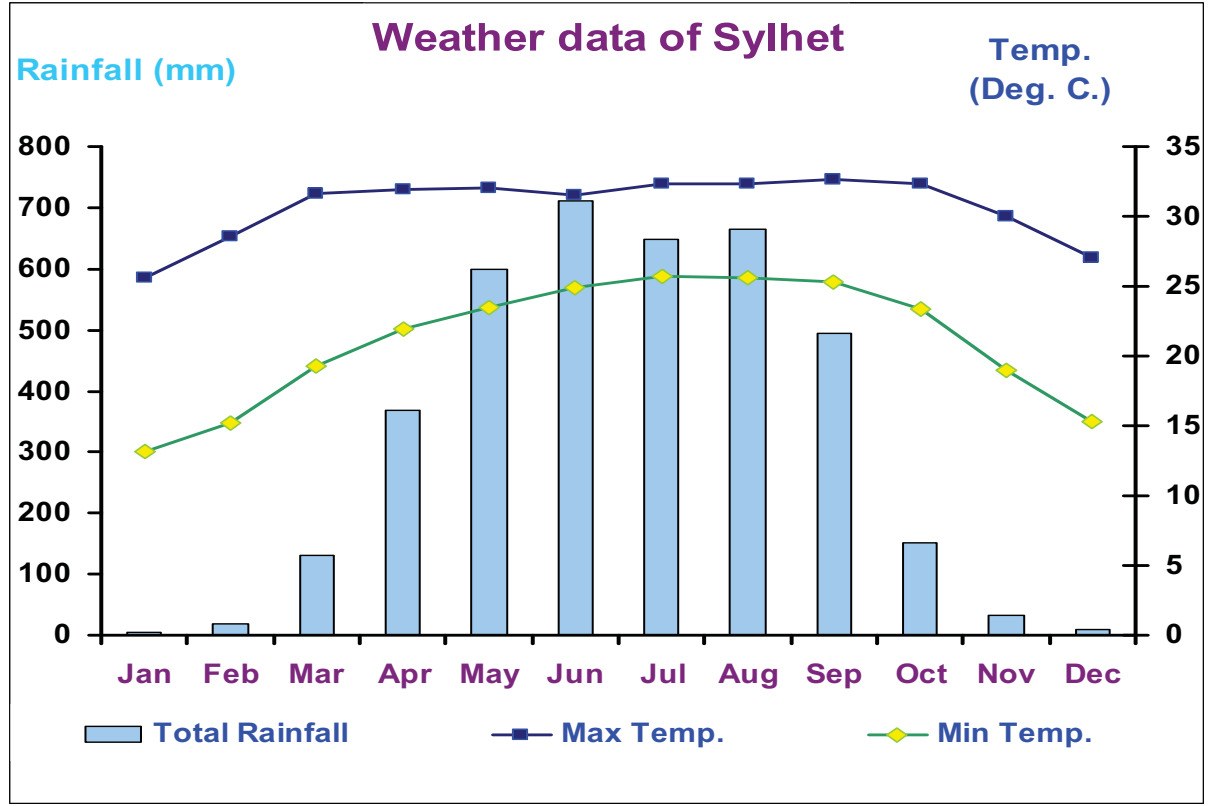

Fig. 1. Annual monthly total rainfall $(\mathrm{mm})$ and temperature during the period 2010-2013 in Sylhet

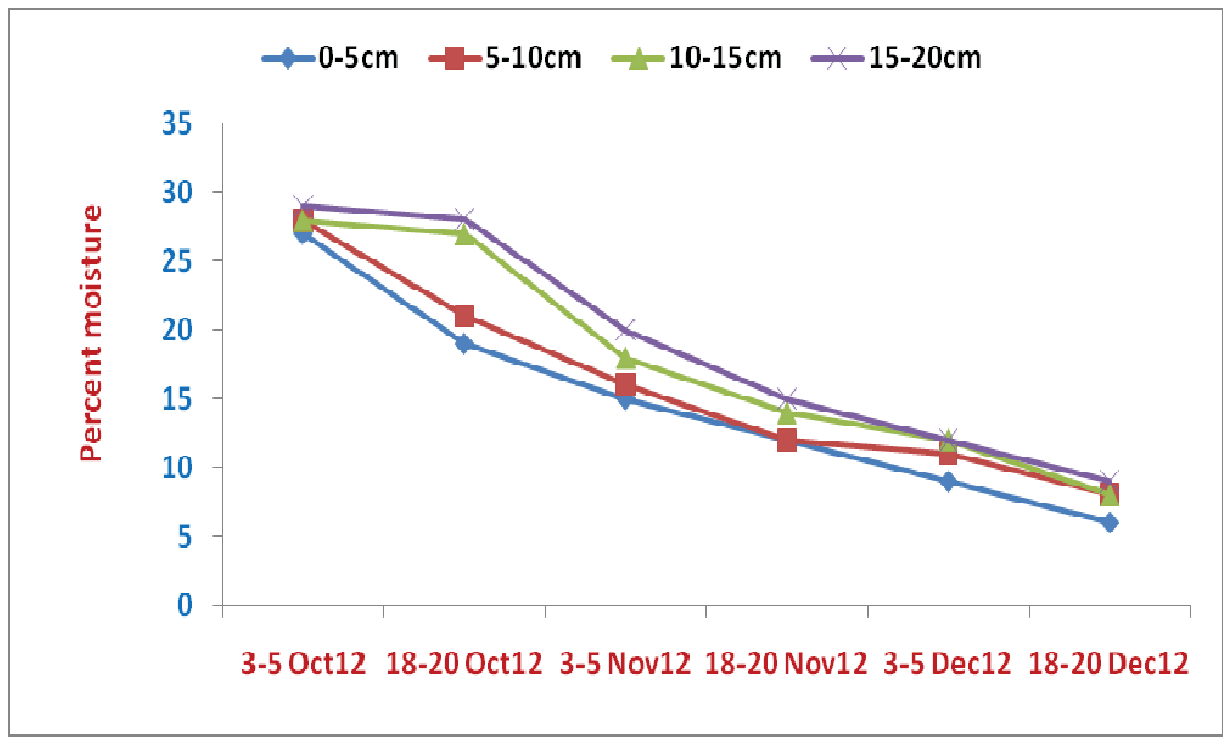

Fig. 2a. The initial soil moisture percent at four different levels of depths of the experimental site during October to November 2012. 
Sweet Gourd as Relay with Transplanted Aman Rice

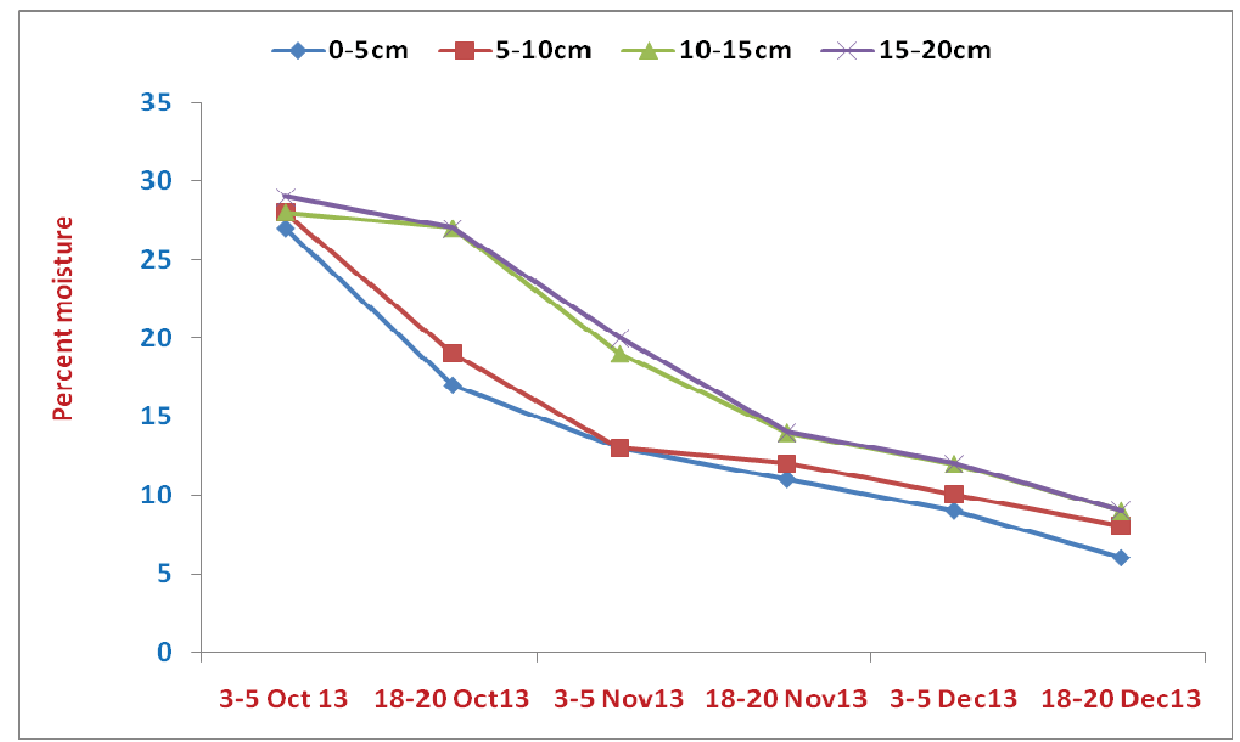

Fig. 2b. The initial soil moisture percent at four different levels of depths of the experimental site during October to November 2013.

\section{Location: MLT Site, Zokigonj}

It was observed that statistically different yields of sweet gourd and $\mathrm{T}$. aman rice were found in both years. The average higher fruit yield of sweet gourd $\left(20.06 \mathrm{t} \mathrm{ha}^{-1}\right)$ was recorded in $\mathrm{T}_{2}(\mathrm{~T}$. aman rice/sweet gourd (var. Hatirpara local) followed by $\mathrm{T}_{1}$ (T. aman rice/sweet gourd var. Mollika), while the lowest yield (14.82 $\left.\mathrm{t} \mathrm{ha}^{-1}\right)$ in case of hybrid variety (Mollika) as a sole crop. Between the two tested sweet gourd varieties, local one (Hatirpara) produced higher fruit yield in both sole and relay cultivation with $\mathrm{T}$. aman rice. This result indicated that the local variety is more adopted or acclimatized than that of hybrid variety (Mollika) in Zokigonj location. On the contrary, the higher grain yield of $\mathrm{T}$. aman rice was recorded from rice as sole crop in both the years. In case of relay cropping, little less yield of $T$. aman rice might be due to hill missing during the preparation of pits for sweet gourd. However, the highest rice equivalent yield $\left(18.84 \mathrm{t} \mathrm{ha}^{-1}\right)$ was recorded in $\mathrm{T}_{2}$ followed by $\mathrm{T}_{1}\left(18.23 \mathrm{t} \mathrm{ha}{ }^{-1}\right)$. Sweet gourd performed better than sole cropping system. It might be due to early sowing of sweet gourd as relay with $\mathrm{T}$. aman rice, which provided very congenial microclimate with utilizing prolonged residual soil moisture than late sowing.

\section{Location: FSRD site, Jalalpur}

The results of two consecutive years reveal that relay cropping system provided the higher fruit yield of sweet gourd rather than sole crop except rice. The average higher fruit yield of sweet gourd (21.73 $\mathrm{t} \mathrm{ha}^{-1}$ ) was produced by $\mathrm{T}_{2}$ ( $\mathrm{T}$. aman rice/sweet gourd (var. Hatirpara local) followed by $T_{1}$ (T. aman rice/sweet gourd var. Mollika), while the lowest yield (16.98 $t$ ha $^{-1}$ ) by $\mathrm{T}_{4}$ (Sweet gourd var. Hatirpara as sole). In the sole cropping systems, the hybrid variety Mollika performed better and produced higher fruit yield (18.36 t ha-1) in Jalalpur. This might be the effect of different soil and micro climatic variation in location to location in Sylhet region. But the sole cropping system $\left(\mathrm{T}_{5}\right)$ of $\mathrm{T}$. aman rice produced higher grain yields than relay in both the years along with average yield of $3.92 \mathrm{t} \mathrm{ha}^{-1}$ (Table 2). On the contrary, relay cropping system 
Nazrul et al.

produced slightly less yield of $\mathrm{T}$. aman rice. It might be due to the area utilized for making pit or mada for relay cultivation of sweet gourd. The averages of rice equivalent yield were also maximum in $\mathrm{T}_{2}$ (19.43 $\left.\mathrm{t} \mathrm{ha}-1\right)$, very close to $\mathrm{T}_{1}\left(18.83 \mathrm{t} \mathrm{ha}^{-1}\right)$. However, the higher yield of sweet gourd in relay might be due to the maximum utilization of soil moisture as well as early sowing of seed.

\section{Cost and return analysis}

Cost benefit analysis of sweet gourd relay with $\mathrm{T}$. aman rice was presented in Table 3 . It is revealed that the highest gross return (Tk. 311040 ha $^{-1}$ ) and net return (Tk.180054 ha-1) was obtained by $\mathrm{T}_{2}$ (T. aman rice/sweet gourd var. Hatirpara local) which also provided highest $\mathrm{BCR}$ (2.37), followed by $T_{1}(2.24)$. This variation occurred due to yields differences of sweet gourd and T. aman rice. The lowest gross return (Tk. $62560 \mathrm{ha}^{-1}$ ) and net return (Tk. $21289 \mathrm{ha}^{-1}$ ) as well as lower BCR (1.51) was gained from the $\mathrm{T}_{5}$ ( $\mathrm{T}$. aman rice as sole).

Table 3. Rice equivalent yield, Cost and return analysis of treatments sweet gourd with T. aman rice as relay cropping system in Sylhet (2012-14)

\begin{tabular}{l|c|c|c|c|c}
\hline Treatments & $\begin{array}{c}\text { Average Rice } \\
\text { equ. Yield } \\
\left(\mathrm{t} \mathrm{ha}^{-1}\right)\end{array}$ & $\begin{array}{c}\text { Gross } \\
\text { return } \\
\left(\mathrm{Tk}_{\mathrm{h}} \mathrm{ha}^{-1}\right)\end{array}$ & $\begin{array}{c}\text { Total cost } \\
\left(\mathrm{Tk} . \mathrm{ha}^{-1}\right)\end{array}$ & $\begin{array}{c}\text { Net return } \\
\left(\mathrm{Tk} . \mathrm{ha}^{-1}\right)\end{array}$ & $\mathrm{BCR}$ \\
\hline $\mathrm{T}_{1}$ (T. aman/sweet gourd var. Mollika) & 18.83 & 301280 & 134736 & 166544 & 2.24 \\
$\mathrm{~T}_{2}$ (T. aman/sweet gourd var. & 19.43 & 311040 & 130986 & 180054 & 2.37 \\
Hatirpara local) & 12.45 & 199200 & 100754 & 98446 & 1.97 \\
$\mathrm{~T}_{3}$ (Sweet gourd var. Mollika sole) & 12.70 & 203200 & 97015 & 106185 & 2.09 \\
$\mathrm{~T}_{4}$ (Sweet gourd var. Hatirpara sole) & 3.91 & 62560 & 41271 & 21289 & 1.51 \\
$\mathrm{~T}_{5}$ (T. aman rice sole) & & & & & \\
\hline
\end{tabular}

*Price of input and output (Tk.kg-1 or Tk/M/Day): Urea-20, TSP-22, MoP-15, ploughing Tk.300 bigha-11, labour-300, sweet gourd seed-150/10g, rice seed-32 and rice non seed- 16.00 and sweet gourd-12.00, pestiside-7539.00.

\section{Conclusion}

From the above finding it may be concluded that the treatment combination $T$. aman rice/sweet gourd (var. Hatirpara local) relay performed better and produced maximum amount of rice equivalent yield with higher BCR (2.37), which was followed by $\mathrm{T}_{1}$ (T. aman rice/sweet gourd (var. Mollika hybrid). Cost benefit analysis revealed that the highest gross return (Tk. 311040 ha $^{-}$ ${ }^{1}$ ) and net return (Tk. 180054 ha $^{-1}$ ) was obtained by $\mathrm{T}_{2}$ (T. aman rice/sweet gourd var. Hatirpara local). Therefore, considering yield, gross return and BCR, the relay cropping of sweet gourd with T. aman rice was found productive and viable for utilizing fallow lands under the Surma Kushiyara Flood Plain soil in Sylhet region.

\section{References}

Black, C. A. 1965. Methods of Soil Analysis: Part I Physical and mineralogical properties. American Society of Agronomy, Madison, Wisconsin, USA.

FRG. 2012. Fertilizer Recommendation Guide, Bangladesh Agricultural Research Council (BARC), Farmgate, Dhaka 1215. 274p.

Gomez K. A. and A. A. Gomez. 1984. Statistical Procedures for Agricultural Research. 2nd Edn. John Wiley and Sons. New York. p.194. 
Sweet Gourd as Relay with Transplanted Aman Rice

Gupta, S. and M. K. Bhowmick. 2005. Scope of growing lathyrus and lentil in relay cropping systems after rice in West Bengal, India. Lathyrus Lathyrism Newsl. 4.

Mondal, M. R. I., M. S. Islam, M. A. J. Bhuiyan, M. M. Rahman, M. S. Alam and M. H. H. Rahman. 2011. Krishi Projukti Hatboi (Handbook on Agro-technology), 5th Edn. Bangladesh Agricultural Research Institute, Gazipur 1701, Bangladesh.

Nazrul, M. I, M. R. Shaheb, A. K. Chowdhury and J. U. Sarker. 2013. Soil Moisture Monitoring in T. Aman Rice Harvested Fallow Land Under Surma Kushiara Flood Plain of Sylhet. Bangladesh Agron. J. 16 (2): 59-66.

Reddy, T. Y. and G. H. S. Reddi. 1992. Principles of Agronomy. Kalyani Publishers. New Delhi-110 002, India. 423.

Singh, C. V., R. K. Singh and V. S. Chauhan. 1990. Relative performance of pigeon pea genotype in sole and rice intercrop systems. Intl. Pigeonpea Newsl. 17: 19-20. 